\title{
VREDNOTENJE GEOGRAFSKEGA OKOLJA IN OKOLJSKA ETIKA
}

\author{
Plut Dušan \\ Oddelek za geografijo, Filozofska fakulteta Univerze v Ljubljani \\ Aškerčeva 2, SI-I000 Ljubljana, Slovenija. \\ e-mail: dusan_plut@t-2.net
}

Izvirni znanstveni članek

COBISS 1.01

\section{Izvleček}

Spremembe v vrednostnih sistemih, načela okoljske etike, se morajo udejaniti v materialnem življenju družbe in posameznika ter vplivati tudi na razumevanje in vrednotenje geografskega okolja. Potreben je premik od pretežno antropocentričnega pojmovanja geografskega okolja, ki ni (več) zgolj arena gospodarstva in bivalno okolje človeka, ima tudi ekosistemski, varovalni pomen.

Ključne besede: geografsko okolje, okoljska etika, trajnostno sonaravni razvoj, nosilna zmogljivost okolja

\section{EVALUATION OF GEOGRAPHICAL ENVIRONMENT AND ENVIRONMENTAL ETHICS}

\begin{abstract}
Changes in the value systems, including the principles of environmental ethics, have to be effectuated in the material life of the society and of individuals, and they also have to exert influence on the apprehension and evaluation of geographical environment. A move must be made forth, away from the mainly anthropocentric apprehension of geographical environment which is no longer merely the scene of economy and the dwelling environment of humans, but it also has the ecosystem, protective significance.
\end{abstract}

Key words: geographical environment, environmental ethics, sustainable development, carrying capacity of environment 


\section{UVOD}

V obdobju 2000-2050 se naj bi globalno gospodarstvo povečalo za 4-krat (Sustainable development...2003, 193). Postavlja se vprašanje, ali lahko tako obsežno svetovno gospodarstvo ustvari manj družbenih in okoljskih stresov kot sedanje, ki je bistveno manjše.

Razen tehnoloških prebojev potrebujemo tudi sveža etična vodila družbenega modela pri poskusu preobrazbe sodobne civilizacije, zasnovana na spravi z naravo, potrebujemo nov etični kodeks človeštva. Izdelati moramo vrednostna merila, vsak od nas pa se bo moral zavedati svoje odgovornosti za današnji in tudi za jutrišnji svet. Živeti bo treba bolj razumno in skladno z naravo, a hkrati odpraviti svetovno revščino. Danes smo na taki razvojni stopnji, da se morajo uveljaviti etične omejitve boja za obstanek tudi v odnosih do narave. Prehod v trajnostno, sonaravno družbo in kulturo ni mogoč brez temeljite spremembe naše celotne duhovnosti, etike, torej spremembe lestvice vrednot. Sodobna etika 21. stoletja naj bi bila zasnovana kot etika odgovornosti do narave, njenega spoštovanja, na razumnosti in zmernosti, na vzgoji odgovornosti človeške vrste do vseh drugih vrst.

Bivanje in materialna dejavnost človeške vrste ter svetovno gospodarstvo so eksistenčno odvisni od geografskega okolja, virov okolja, delovanja planetarnega ekosistema. Geografsko okolje ni zgolj arena gospodarstva in bivalno okolje človeka, opravlja tudi številne ekosistemske storitve (storitve okolja), ki so ključne za ohranjanje eksistenčnih pogojev za človeško in tudi za druge vrste. Eden od ključnih pogojev udejanjanja okoljske etike je tudi večplastno in optimalno (razvojno-varovalno), ne le ozko ekonomistično (izkoriščanje sestavin okolja, naravnih virov) in potrošniško zasnovano vrednotenje geografskega okolja in njegovih sestavin.

\section{OKOLJSKA ETIKA IN VREDNOTENJE RAZMERJA ČLOVEK OKOLJE}

Socializem in tudi trdi razsvetljenski liberalizem v družbah s parlamentarno demokracijo sta po mnenju Hribarja (1991) zabredla v nasilje. Ne toliko v nasilje nad človekom, kot v nasilje nad naravo, s katero le-ta ravna kot z objektom. Tako kot trajnostni sonaravni razvoj trajno ni mogoč brez okoljskih/ekoloških omejitev in drugačne razdelitve bogastva, tako trajno tudi ni možen sedanji način globalizacije s poglabljanjem socialnoekonomskih razlik in vse večjimi okoljskimi pritiski.

V 20. stoletju se je torej razmerje med človekom (družbo) in geografskim okoljem temeljito spremenilo, pri čemer človek vse bolj obsežno in intenzivno posega v okolje. Hkrati $\mathrm{z}$ antropogenimi spremembami $\mathrm{v}$ okolju, popolnejšim poznavanjem delovanja geosfere in negativnih vplivov človeka se je začelo spreminjati tudi razmišljanje o odgovornosti človeške vrste do ohranjanja varnega in zdravega okolja za človeka in druge vrste, odgovornosti tudi do prihodnjih generacij.

Po mnenju Ferryja (1998) in Jonesa (2004) obstojajo naslednje temeljne različne smeri o vodilnem vprašanju odnosov med človekom in naravo:

1. prek narave je treba vedno in povsod ščititi človeka, okolje nima sebi lastne, notranje vrednosti, ni entiteta - antropocentrična smer; 
2. ne smemo le iskati koristi za ljudi, temveč je potrebno vsa bitja, ki lahko občutijo ugodje in trpljenje (torej živali), obravnavati kot pravne subjekte ( plitva ekologija oziroma »okoljska ekologija «) - reformistična antropocentrična smer kritike modernosti z etiko okolja oziroma okoljevarstveno etiko;

3. potrebno je varovati tudi ekosisteme (vključno z neživimi sestavinami), biosfero, naravo, kozmos pred človekom (biocentrična oziroma ekocentrična ekologija), katerim je podeljena lastna, notranja vrednost - radikalna ekocentrična smer oziroma globinska ekologija (deep ecology). Le-ta zahodno civilizacijo antropocentristične modernosti ocenjuje kot popoln civilizacijski polom in poudarja naravovarstveno etiko.

Antropocentrizem izhaja iz predpostavke o dominaciji človeške vrste, ki je povzročila izčrpavanje naravnih virov in slabšanje kakovosti okolja. Utemeljuje in opravičuje človekov gospodovalni odnos v naravi (Kirn 2004, 180). Trajnostno sonaravni pogled na svet je zasnovan zlasti na pojmovanju planeta kot vesoljske ladje in delno na biocentrizmu, odraža se v podpori organskemu kmetijstvu, reciklaži in rabi obnovljivih virov energije. Eko (bio)centrizem pa je zasnovan na predpostavki ekoloških principov, kjer so posamezne vrste podrejene širšim procesom delovanja svetovnega bioma. Pogin posamezne živali ali rastline povzroča probleme ekosistemom, izumiranje vrste pa lahko povzroči resne posledice na celotno evolucijo.

V 70. letih prejšnjega stoletja se je začela oblikovati okoljska (ekološka) etika, ki v bistvu zahteva nov razmislek o človekovem odnosu do vsega živega in izrecno poudarja etično odgovornost do ekoloških pogojev prihodnjih generacij. Ošlaj (2007) upravičeno opozarja na neenotnost poimenovanja teorije predmeta človekovega etičnega delovanja do narave (ekološka etika, okoljska etika, etika narave itd.). Osnovna značilnost širšega moralno vrednotnega odnosa je po mnenju Kirna $(2004,159)$ v tem, da se presoje o ravnanju človeka razširijo še na bogastvo človekovih razmerij do živali, rastlin, ekosistemov, narave in življenja nasploh. Okoljska etika torej prinaša nov izziv dosedanji etični tradiciji zlasti zahodne civilizacije, zahodnega humanizma in njegovih religiozno-filozofskih in političnih konceptov. Zajema uporabnost etičnih izhodišč za odločanje o problematiki okolja, njen ključni vidik so moralna razmerja med človekom in drugimi vrstami in naravnih okoljem, ki vključuje tudi nežive sestavine. $Z$ biološko - ekološkega vidika etika ni samo omejitev človekove akcije v boju za obstanek, temveč je tudi omejitev stalno rastočega človekovega materialnega razkošja v biosferi, ne glede na življenjske potrebe in razmere drugih bitij. Moralna omejitev boja za obstanek je v človeški zgodovini veljala le znotraj družbe do ljudi, medtem ko do narave (drugih vrst) omejitev ni bilo. »Ekološka« kriza opozarja na dvojno odgovornost, ki ni (več) utemeljena $\mathrm{z}$ antropocentričnimi argumenti (skrb za prihodnje generacije), temveč tudi z biocentričnimi (narava kot avtonomno vrednostno področje) (Ošlaj, 2007).

Okoljska etika oziroma okoljevarstvena etika je praviloma etični kompas ti. plitve ekologije, na katerem je zasnovan trajnostno sonaravni model razvoja. Prednostno je sicer zasnovana na varstvu okolja in naravnih virov (antropocentrični vidik), a vključuje tudi elemente varstva narave (ekocentrični vidik), zlasti pravic živali in ohranjanja nedotaknjenosti narave v omejenem obsegu. Narava ni problem, problem je človek in njegov odnos do narave (Anko 2000). Nove oziroma pozabljene vrednote naj bi izhajale iz pojmovanja 
človeške vrste kot dela narave, odvisnega od kakovosti temeljnih virov okolja (Marsh in Grossa 2002). Ohranjanje baze kritičnih virov okolja pomeni ohranjanje bioloških pogojev življenja sedanje in prihodnjih generacij. To npr. pomeni, da kmetijska raba zemljišč ne sme na račun kratkoročnih dobičkov trajno izčrpavati rodovitnosti prsti in onesnaževati oskrbno pomembne vodne vire.

Po mnenju biologa Oduma $(1989,267)$ ohranjanje in izboljšanje kakovosti okolja zahteva tudi etično zasnovano podporo. Neetično naj bi bilo vsako ravnanje, ki je v nasprotju z naravo, z delovanjem temeljnih življenjskih oskrbnih sistemov in zmanjšuje nosilne zmogljivosti okolja za prihodnje generacije. Pritiski posameznika in lokalne akcije, sprememba vrednostnega sistema, potreb in želja so ključne za spremembe ravnanja z okoljem. Po mnenju Kryštufeka (1999) npr. varstvena biologija kot znanost o biodiverziteti dejansko opravičuje svoj obstoj z etičnimi načeli, npr, da je biološka raznovrstnost vrednota sama po sebi, torej ni odvisna od ekonomske vrednosti vrste.

Znanstveni in tehnološki razvoj industrializma se žariščno ukvarja z rastjo kot ciljem. Prihaja obdobje, ki zahteva upoštevanje socialnih, okoljskih in etičnih posledic enostransko pojmovanega razvoja človeštva, kar prinaša nujnost sprememb obnašanja v odnosu do narave, okolja in prihodnjih generacij. Po mnenju Kupchella in Hylandove $(1996,559)$ bi morala postati okoljska (ekološka) paradigma osnova vseh etičnih sistemov, izobraževanje pa bi se preusmerilo od koncepta »imeti« k proučevanju razmerja človek-okolje. V izobraževanju je potrebno opozarjati na odgovornost do prihodnjih generacij in globalen pristop, ki bo opozoril na jalovost neskončnega kopičenja bogastva, ki naj bi ga predali naslednjim generacijam. Zapustili jim bomo namreč tudi uničen, izčrpan planet, na katerem bo propadalo gospodarstvo in prišlo do socialne dezintegracije.

Za uveljavitev okolju prijaznejše in hkrati pravičnejše, solidarne družbe je pomembna tudi večja materialna enakost med ljudi in med državami (Požarnik 1999). Tradicionalne cilje izobrazbe »branje, pisanje in računanje« je potrebno dopolniti z »ekologijo, ekonomijo in socialno pravičnostjo«, interdisciplinarnim in sistemskim pristopom, krepitvijo sposobnosti odgovornega sprejemanja odločitev tudi ob upoštevanju potreb prihodnjih rodov in biosfere. Hkrati je potrebna globalna ekološka zavest, globalni ekološki državljan, ki naj bi po mnenju Kirna $(2004,219)$ ravnal po načelu »misli globalno, deluj lokalno«. Danes se še mnogi namreč ne zavedajo, da sta vožnja z avtomobilom in goveji zrezek na krožniku prav tako povezana s segrevanjem ozračja, kot proizvodnja in potrošnja električne energije iz termoelektrarne.

Nekatere od radikalnih sonaravnih etičnih alternativ pozivajo $\mathrm{k}$ odpravi potrošniške družbe in tehnologij, ki so v službi neetične, tudi socialno nepravične sodobne industrijske družbe. Razviti je treba razumnejše, bolj ekološke, kulturne, socialne, pravične in duhovne oblike življenja, ki sedanjega materialnega načina življenja ne podaljšujejo v prihodnost. Družba se bo morala odločiti, kako bo zmanjšala potrošnjo in stroške zmanjševanja razporedila med gospodinjstva in državo. Odpirajo se etične dileme in pripravljenost sedanje generacije (altruizem), da sprejme odgovornost, kdo bo nosil breme ohranjanja možnosti napredka prihodnjih generacij. Neetično naj bi bilo vsako ravnanje, ki je v nasprotju z naravo, z delovanjem temeljnih življenjskih oskrbnih sistemov in zmanjšuje nosilne zmogljivosti okolja za prihodnjo generacijo. 
Sodobne mednarodne deklaracije obotavljivo in dokaj nedorečeno vključujejo med temeljne vrednote spoštovanje narave, okolja, torej ti. okoljske vrednote. Kljub temu so trenutno prevladujoči vrednosti sistemi še vedno antropocentrično zasnovani in precej oddaljeni od bistveno širše zastavljene in celovitejše okoljske etike.

Potrebujemo torej nove vrednote, ki bodo izhajale iz dejstva, da je človeška vrsta (le) del okolja, od katerega je eksistenčno odvisna (Marsh in Grossa 2002, 36). Globalni in lokalni okoljski problemi in okoljska gibanja po mnenju Kirna $(2004,222)$ dolgoročno vodijo k temeljnim, skupnim univerzalnim ekološkim/okoljskim vrednotam. To še ne pomeni, da jih sprejemajo vsi, ampak vsaj velika večina. Prevladujoča človeškosrediščna etika se postopoma dopolnjuje z nekaterimi izhodišči globalno ekocentrične etike. Ostaja namreč dejstvo (Ošlaj, 2007, 17): človek je iz narave postavljen v naravo in priti njej; toda da bi kot vrsta preživel, mora z njo sklepati kompromise.

Geografske raziskave kot opozorila o izčrpavanju naravnih virov in obsežni degradaciji geografskega okolja so sovplivale na navedeno postopno spreminjanje vrednot, okoljska etika pa povratno vpliva na spremembe pojmovanja in vrednotenja geografskega okolja.

\section{GEOGRAFSKOVREDNOTENJEOKOLJAINIZZIVIOKOLJSKE ETIKE}

Načela okoljske etike prinašajo geografiji kot vedi o razmerju med človekom in geografskim okoljem oziroma naravo številne vsebinske izzive in metodološke razmisleke. Po mnenju filozofa Ošlaja (2007) je vsako človekovo razmerje do narave vrednostno strukturirano.

Geografsko okolje je v 20. stoletju doživelo temeljito antropogeno preobrazbo, številne pokrajine sveta so onesnažene, pokrajinsko degradirane, naravni viri izčrpani. Pred geografijo je torej priložnost in naloga, da glede na teoretično-metodološki in vsebinski potencial, »mostiščno« vlogo med družboslovno-humanističnimi in naravoslovnimi znanostmi prispeva konkretni kamenček k mozaiku prepotrebnega drugačnega človekovega odnosa do okolja, prihodnjih generacij, drugih vrst. Z vidika geografije in njenega pojmovanja razmerja med človekom in okoljem so ključna naslednja polja okoljske etike (Plut 2004):

- Ne zgolj lokalna in regionalna, temveč tudi planetarna okoljska (ekosistemska) odgovornost - izboljšanje lokalnega okolja ne sme potekati na račun splošnega poslabšanja okolja v širši okolici;

- $\quad$ ravnovesje ciljev napredka - ravnovesje med gospodarskimi, socialnimi, regionalnimi in okoljskimi koristmi;

- $\quad$ socialna (družbena) pravičnost - človeka vreden, a zmeren materialni standard za vse prebivalke in prebivalce, odprava revščine;

- medgeneracijska enakost oziroma odgovornost - trajno ohranjanje eksistenčnih pogojev življenja;

- $\quad$ odgovornost do živalskih in rastlinskih vrst - prepoznavanje t.i. notranje vrednosti narave, razmerje do drugih vrst. 
Navedena polja okoljske etike geografiji kot vedi o prostoru, površinski sferi, geografskemu okolju, geosferi, pokrajini prinašajo med drugim tudi potrebo po razširjenemu, večplastnemu pojmovanju in vrednotenju prostora, geografskega okolja. Prostor je celota fizičnih pojavov, procesov na Zemljinem površju, nad in pod njim, do koder sežejo neposredni vplivi človekovih dejavnosti (Geografski terminološki slovar 2005, 322), geografski prostor je trodimenzionalno območje Zemljinega površja (Geografski terminološki slovar 2005, 112), obstoja v (določenem) času in na določenem kraju (Vrišer 1998, 12). Černe $(2005,239)$ se strinja, da je prostor najpogosteje izražen v obliki zemljinega površja, vendar poudarja, da je $\mathrm{z}$ vidika prostorske analize ključno raziskovanje prostorske stvarnosti kot prostorske strukture. $Z$ vidika okoljske etike velja podčrtati naslednje ključno izhodišče: prostor ima omejene sposobnosti tako za nameščanje razvoja kot tudi rasti. Povedano drugače: stvarni fizični prostor predstavlja veliko prostorsko areno človekove materialne dejavnosti, a je hkrati univerzalna omejitev materialnega razvoja človeštva pri razmeščanju dejavnosti. Okoljska etika ponovno aktualizira tudi naslednji geografski prostorski vidik: človek je vedno $\mathrm{v}$ in $\mathrm{s}$ prostorom, katerega spreminja in je hkrati tudi izpostavljen določenim prostorskim vplivom (Černe 2005, 242). Na drugi strani pa po mnenju geografa Murdocha $(2006,194)$ človekova odgovornost do drugih vrst in ekosistemov dodatno poudarja, da bogato, raznovrstno okolje (v razliko od enostavnega, osiromašenega) prinaša koristi tudi človeštvu.

V sodobni družbi se pojem okolje veliko uporablja, vendar v zelo različnem pomenu: nekaterim je sinonim za naravo, drugi poudarjajo tudi antropogene elemente (kulturna kmetijska, urbana pokrajina), pomen naravnih virov in storitev okolja (Gilpin 1996, 74). Kirn $(2004,13,14)$ ugotavlja, da termin okolje izpodriva termin narava, kar na jezikovni ravni izraža proces vraščanja sociosfere v naravo, v biosfero. Prevlada pojma okolja nad naravo kaže na obseg in globino človekovega preoblikovanja narave.

Okoljska etika izrazito poudarja potrebo po večplastnosti razumevanja pomena okolja. Geografija uporablja pojem geografskega okolja, njegove definicije pa so zaradi osnovnega geografskega predmeta (razmerje in pokrajinske/prostorske posledice razmerja človek/družba - okolje) praviloma zasnovane na preseganju dualističnega ločevanja med naravnim in antropogenim okoljem (celovitost okolja) in izhajajo iz antropocentrične etične opredelitve. Okolje je po mnenju Haggetta $(1972,10)$ vsota vseh pogojev, razmer, ki obkrožajo človeka na vsaki točki planeta. $Z$ razvojem civilizacije se je naravno okolje spreminjalo in nadomeščalo $\mathrm{z}$ antropogenimi elementi. Radinja $(1974,38)$ poudarja, da celotno razumevanje in proučevanje geografskega okolja dejansko potrjuje smisel geografije kot kompleksne vede. Tudi Vrišer $(1998,9)$ poudarja enotnost geografskega okolja (prirodno okolje $\mathrm{z}$ antropogenimi elementi), saj geografsko okolje označuje tisti materialni svet, $v$ katerem živi in deluje že več tisočletij človeška družba. Nujnost celovitosti geografskega okolja in njegovo antropocentrično vrednotenje je poudarjeno tudi v definiciji geografskega okolja v Geografskem terminološkem slovarju $(2005,112)$ : geografsko okolje označuje splet za geografijo pomembnih naravnogeografskih in družbenogeografskih pojavov, prvin in procesov, pomembnih za življenje ljudi. (Geografski terminološki slovar 2005, 112). V Geografskem terminološkem slovarju (2005, 262) pa je okolje označeno kot prostor, ki s svojimi sestavinami omogoča življenje na Zemlji in vpliva nanj, oziroma kot biotske in abiotske sestavine, $s$ katerimi je organizem v snovni, 
kemični ali/in energijski povezavi. V razliko od definicije geografskega okolja je definicija okolja torej naravoslovno pogojena.

Geograf Kemp $(2004,411)$ ne uporablja pojma geografsko okolje temveč okolje, katerega definira kot kombinacijo različnih fizičnih in bioloških elementov, ki vplivajo na življenje organizma. Po mnenju geografov Marsha in Grossa (2002) je za geografijo osrednje vsebinsko polje raziskovanje človekove preobrazbe Zemlje. Poudarjata, da se sodobno preučevanje okolja osredotoča na rabo zemljišč, onesnaževanje okolja in okoljske vplive. Špesova (1994) pa sodi, da je potrebno razen geografskega raziskovanja okolja in njegovih sestavin upoštevati tudi zaznave in odnos prebivalcev do okolja.

Okoljska etika torej v geografsko polje prinaša ali dodatno argumentira naslednja vsebinska polja in večplastno vrednotenje geografskega okolja:

1. geografsko okolje - kakovostna in zdrava prostorska arena: varstvo okolja;

2. geografsko okolje - omejena shramba naravnih virov (energije in surovin) in sprejemnik emisij in odpadkov: varstvo naravnih virov oziroma virov okolja;

3. geografsko okolje - eksistenčna nujnost opravljanja ekosistemskih storitev oziroma storitev okolja: varstvo narave, pokrajine.

Narava je torej vir dobrin, vendar so od procesov v naravnih sistemih odvisne osnovne življenjske razmere, ki omogočajo preživetje človeka pa tudi drugih organizmov (Gaberščik 2007). $Z$ vidika udejanjanja nekaterih ključnih načel okoljske etike $v$ geografijo se strinjamo z naslednjim razmišljanje geografov Beaumonta in Phila (2004), da je za geografsko pojmovanje okolja razen interakcij med fizično (naravno) in kulturno pokrajino v sedanji stopnji environmentalizma pomemben tudi materialno-tehnični in politični vidik, pa tudi etični in duhovni, saj je človeštvo za stanje okolja zaradi vse bolj obsežnih posegov tudi odgovorno.

Večplastno, razvojno-varovalno in bivalno vrednotenje geografskega okolja odpira vsebinsko in terminološko upravičenost zgolj razvojno pojmovane vsebine naravnega vira, kjer je seveda v ospredju ekonomski pomen. Številni raziskovalci okolja sodijo, da je tudi zaradi sodobnega, večplastnega pojmovanja (geografskega) okolja potrebno poudariti razen tradicionalne razvojne tudi varovalno vrednotenje naravnega vira, torej večplastni pomen naravnega vira poudariti z rabo pojma okoljski vir oziroma vir okolja. Okoljski viri so vsi deli narave, ki jih človeštvo ocenjuje kot uporabne, pa tudi kot vredne (Mather in Chapman 1995, 1). Okoljske vire lahko definiramo kot tiste dele narave, ki lahko človeku zagotavljajo dobrine (surovine, energija), prostor za dejavnosti in storitve, vključno s ekosistemskimi, kot so zmogljivost samočiščenja, proizvodnja kisika, možnosti za rekreacijo, vrednotenje pejsažne lepote ali možnost odlaganja odpadkov. Za razliko od naravnih virov, kjer je v ospredju vrednotenje njihovega ekonomskega pomena, vključujejo okoljski viri tudi tržno neovrednotene ekosistemske storitve, zato je vrednotenje okoljskih virov (virov okolja) širše, razvojno (ekonomsko-tehnološko) in varovalno (ekosistemsko) uravnoteženo. Praviloma se ekosistemske storitve obravnavajo v okviru posameznih obnovljivih naravnih virih, npr. vodnih virih, zraku, prsti, biomasi in prostoru (odprti prostor - gozdna in kmetijska zemljišča). Med ekosistemskimi storitvami se pri razvojnemu vrednotenju naravnih virov namenja večja pozornost zmogljivostim samočiščenja, zlasti pri vodi, zraku, prsti in vegetaciji. 
Dosedanje geografsko pojmovanje okolja se je glede na razvojne faze preobrazbe geografskega okolja, pokrajine upravičeno osredotočilo na poudarjanje nujnosti celovite obravnave okolja, vlogo človeka pri preobrazbi in pomen varstva okolja z vidika kakovosti življenja za človeka (varstvo bivalnega okolja). Sedanja stopnja in obseg degradacije geografskega okolja, okoljska globalizacija, sonaravna paradigma in načela okoljske etike (povezava antropocentrizma in ekocentrizma) pa pred geografske okoljske raziskave postavlja nove vsebinske izzive, predvsem potrebo po razširjeni obravnavi in večplastnemu pojmovanju in vrednotenju geografskega okolja, vključno s potrebo po varovanju virov okolja, celotne pokrajine, pokrajinske (in s tem biotske) (geo)raznovrstnosti. Geografsko in celostno zasnovano prepoznavanje nosilnosti okolja na različnih prostorskih ravneh in potreba po širšemu ekonomskemu in ekosistemskemu vrednotenju okolja ter virov okolja sta ključni vsebinski geografski okoljski priložnosti.

Sodobni koncept večplastno pojmovane nosilne zmogljivosti okolja (krajše - nosilnosti okolja) postaja torej temeljen za ocenjevanje še sprejemljivih posegov človeka v geografsko okolje. Raven in stopnja izčrpavanja naravnih virov in obremenjevanja okolja ne sme biti večja in hitrejša od regeneracijskih ali absorpcijskih (asimilacijskih) sposobnosti sistemov okolja, od samočistilnih sposobnosti (regeneracijskih in nevtralizacijskih) (Špes in drugi 2002). Ocena obsega in stopnje samočistilnih sposobnosti (nevtralizacijskih in regeneracijskih) določene pokrajinskoekološke, geografske enote je eden od geografsko zasnovanih načinov ocene sicer večplastno zasnovane nosilnosti okolja.

Geografsko pojmovanje koncepta nosilne zmogljivosti z vidika človeške vrste vključuje in povezuje biološko ter kulturološko pojmovanje nosilnosti okolja. Biološko pojmovanje nosilne zmogljivosti človeške vrste je definirano s številom svetovnega prebivalstva, ki jih lahko prehrani planet, torej ne vključuje kakovosti življenja, druge vrste, okoljske motnje. Kulturološko, širše geografsko pojmovanje nosilne zmogljivosti (nosilnosti okolja) pa je definirano $\mathrm{s}$ številom prebivalcev planeta, ki naj bi živelo $\mathrm{v}$ dolgotrajnem, trajnostnem ravnovesju z okoljem na primerni kakovosti življenja, s sistemi trajno ne-degradirane rabe zemljišč (Marsh in Grossa 2002, 9). Širše, geografsko pojmovanje nosilne zmogljivosti ne vključuje torej le možnosti trajne proizvodnje hrane (ohranjanje prsti in vode) za človeštvo, temveč tudi ohranjanje drugih oblik življenja ter sestavin okolja, ki nimajo neposrednih in takojšnjih ekonomskih vrednosti.

Človeštvo se dejansko postopoma približuje zgornjim mejam nosilnosti planeta, spremembe svetovnega ozračja zaradi emisij človekovih dejavnosti pa opozarjajo, da so te meje $\mathrm{v}$ posameznih primerih z veliko verjetnostjo že presežene. Eden od sintezno zasnovanih kazalcev, ki izhajajo iz širše pojmovane nosilnosti okolja, so ekološki, okoljski odtisi (stopinje, sledi). Izračunavanje ekološkega odtisa temelji na seštevanju površin, potrebnih za proizvodnjo hrane in vlaken, za absorpcijo odpadnih snovi, ki so posledica rabe energije in površin, namenjenih raznovrstni infrastrukturi (Plut 2004, Vintar Mally 2006). Končni preračun potrebnih bioproduktivnih površin na prebivalca torej izhaja iz obsega obstoječe potrošnje, ki je lahko nad ali pod globalno ali regionalno razpoložljivo biokapaciteto. Strokovnjaki sodijo, da s sedanjimi tehnologijami in povprečno ravnijo potrošnje sedanje število svetovnega prebivalstva vsaj za petino presega bioprodutivnost planeta. Tako je leta 2003 povprečni ekološki odtis znašal 2,23 globalne ha, biokapaciteta planeta pa je bila 1,78 gha. $V$ gospodar- 
sko razvitih državah je leta 2003 povprečni ekološki odtis bil 6,4 gha na prebivalca (Slovenija 3, 4 gha), v srednje razvitih državah 1,9 gha na prebivalca, v revnih državah pa 0,8 gha na prebivalca. Povprečna poraba naravnih virov in pritiski na okolje so torej v najbolj razvitih državah za več kot 3-krat presegali planetarno bio-zmogljivost okolja.

Geograf Kemp $(2004,151,152)$ poudarja, da je v sodobnem, tržno zasnovanem finančnem sistemu vrednost vira določena s ceno, ki jo je pripravljen plačati posameznik ali skupina. Številni naravni viri, ki opravljajo okoljske, ekosistemske storitve, pa niso vključeni v navedeni tip gospodarstva, zato jih družba ignorira ali finančno podcenjuje. Poskus izračuna ekonomske vrednosti svetovnih okoljskih dobrin in storitev je pokazal, da je ovrednotena skupna letna finančna vrednost (33 trilijonov dolarjev) za 1,8-krat presegla takratni letni globalni bruto družbeni dohodek (Constanza in drugi 1997). V primeru, da bi se odločili ekosistemske storitve vključiti v svetovno gospodarstvo, bi bil globalni sistem cen bistveno drugačen od obstoječega. Cene dejavnosti, ki neposredno ali posredno uporabljajo ekosistemske storitve, bi bile bistveno višje (Constanza in drugi 1997, s. 259). Struktura plačil, vključno s plačami, dobički bi se dramatično spremenili. Svetovni BDP bi bil spremenjen po obsegu in sestavi, v kolikor bi vključil cene ekosistemskih storitev. Edina nadaljnja pot za blaginjo človeštva je ohranjanje procesov v naravi in popravilo nastale škode (Gaberščik 2007). Hkrati bi moralo večje obdavčenje okoljsko destruktivnih dejavnosti nadomeščati zmanjšanje obremenitev dohodkov (Brown 2006, 265).

Zmogljivost okolja glede oskrbovanja $\mathrm{z}$ naravnimi viri in absorpcije emisij in odpadkov predstavlja absolutno omejitev človekovih dejavnosti. Princip okoljske zmogljivosti zahteva, da so regije, mesta oblikovana in vodena znotraj omejitev, ki jih postavlja naravno okolje. Prepoznavanje omejenih zmogljivosti naravnega okolja za sprejemanje emisij in odpadkov, omejenosti naravnih procesov obnavljanja ter okoljska ekonomizacija (razvojno-varovalna) virov okolja prednostno določajo okoljske smernice za globalno in regionalno »eko - rekonstrukcijo« poselitve, proizvodnje in potrošnje, geografiji pa ponuja raziskovalno in izobraževalno priložnost.

\section{SKLEP}

Po mnenju Kirna (2004) obstoječi način poteka globalizacije in potrošništvo pospešeno potiskajo celotno svetovno gospodarstvo k globalnim ekofizičnim omejitvam. Hkrati pa zaradi svetovne revščine in velikih razlik v (ne)blagostanju prihajamo k zgornjim mejam tolerantnosti socialnoekonomskih razlik različnih prostorskih ravneh, od globalne do lokalne. Zato je tudi večplastno, torej okoljsko (ekosistemsko), ekonomsko in družbeno, etično vrednotenje spremenjene vloge geografskega okolja eden od ključnih dejavnikov v iskanju trajnih poti blagostanja človeštva in biosfere. Pojmovanja, znanja, vrednotenja o geografskem okolju kot viru surovin in energije ter nezamenljivi, zdravi areni človekovega bivanja sedanjih generacij, bo potrebno razširiti na obravnavo geografskega okolja kot arene bivanja vseh vrst in prihodnjih generacij. Tako zasnovano geografsko okolje bi moralo postati eden od temeljev udejanjanja sonaravnih etičnih izhodišč (okoljska etika) in polje splošne izobrazbe. Geografskemu okolju prijazno obnašanje družbe kot celote namreč lahko dosežemo le tam, kjer so ljudje ozaveščeni o posledicah lastnega poseganja v okolje (Vovk Korže 1997). 
Geografija kot znanost in šolski predmet lahko prispeva pomemben delček k jasnemu prepoznavanju večplastnosti okoljskih problemov sodobnega sveta, kot predpogoja pričakovanega in želenega smotrnega (sonaravnega) lokalnega, regionalnega in planetarnega ravnanja posameznika, skupine, regije, države, skupine držav, človeštva. Sposobnost občutljive zaznave, razumevanja in razlage pokrajinskih sprememb, neskladnosti v sestavi in dinamiki geografskega okolja, okoljskih razsežnosti sinergizma procesov v pokrajini ter prepoznavanje geografskih potencialov in omejitev, je osnova za odgovoren odnos in primerno okoljsko ukrepanje države in posameznika. Geografija opozarja na nujnost širokega pojmovanja geografskega okolja, ki se je zlasti zadnjih tristo let obravnaval zgolj kot neskončna shramba dobrin, gospodarska dejavnost pa je zgolj posnemala metode rudarstva.

Geografsko, torej celostno zasnovano raziskovanje vzrokov in zlasti posledic odnosa človek - okolje, lahko prispeva pokrajinski kamenček pri napornemu in dolgotrajnemu dograjevanju okoljske etike ter sonaravnega mozaika živega planeta, njegovih sestavin in regij. Zgolj sicer prepotrebna sprememba naših vrednot, "sonaravnega« pojmovanja geografskega okolja pa ne bo sama po sebi izboljšala njegovo kakovost, potrebna je sonaravna praksa na globalni, državni, regionalni in individualni ravni. Po mnenju geografskega vizionarja Haggetta $(1972,461)$ naj bi geografija kot družbeno pomembna aplikativna znanost pronicljivo iskala srednjo pot med izkoriščanjem in onesnaževanjem naravnega okolja zaradi kratkoročnih ekonomskih (razvojnih) koristi in med nerealističnim sanjarjenjem o pastoralnem, v celoti zaščitenem, a neproduktivnem svetu. Okoljska etika je navedena vizionarska razmišljanja dogradila predvsem $\mathrm{z}$ upoštevanjem posledic sprememb geografskega okolja za druge vrste in prihodnje generacije, a ni prezrla znotrajgeneracijsko potrebo po družbeni pravičnosti. Geografija torej v turbolentnem značaju razmerij družba - okolje lahko igra pomembno vlogo pri potrebni »ekologizaciji« sveta s poudarjanjem njegove kompleksne materialne, prostorske heterogenosti, pa tudi pri udejanjanju okoljsko (planetarna soodvisnost in solidarnost, misli globalno - deluj lokalno) in socialno (družbena pravičnost, medgeneracijska enakost) relevantnih, povezanih načel okoljske etike.

Ker smo kot geografi praviloma celostno izobraženi posamezniki, z obilo geografsko okoljskih informacij, s prepotrebno okoljsko etiko in z želenimi nekaterimi lastnimi primeri uspešne okoljske prakse, lahko pomembno sovplivamo zlasti na medgeneracijski prenos okoljsko pomembnih informacij o pomenu ohranjanja ekosistemskih funkcij planeta, izčrpavanju geografskega okolja in težavnih, a nujnih, svežih sonaravnih poteh človeškega napredka.

Z vidika razvojno-varovalnega pojmovanja geografskega okolja ni več ključno geografsko vprašanje »kje«, temveč »zakaj ravno tam«?

\section{Viri in literatura}

Anko, B., 2000. Kako ohranjati (in ohraniti) najvrednejšo naravo? Naprej k naravi II (zbornik). Ljubljana, str. 241-251.

Beaumont, P., Philo C., 2004. Environmentalism and Geography. Unifying Geography. Routledge, London and New York, str. 94-116.

Berry, W., 2004. Global Problems, Local Solutions, Ekorega, Ljubljana. 
Brown, L., 2006. Plan B 2.0: Rescuing a Planet under Stress and a Civilization in Trouble. Earth Policy Institute, New York.

Constanza, R. in drugi, 1997. The Value of the World's Ecosystem Services and Natural Capital. Nature 387/15, str. 253-259.

Černe, A., 2005. Pandorina skrinjica-geografski pogledi na prostorske analize v planiranju. Dela 23, Ljubljana, str. 235-244.

Ferry, L., 1998. Novi ekološki red. Krtina, Ljubljana.

Gaberščik, A., 2007. Narava je kapital. Zbornik Okoljske akademske mreže 2007/1, Fakulteta za družbene vede, Ljubljana, str. 22- 26

Geografski terminološki slovar. 2005. ZRC SAZU, Ljubljana.

Gilpin, A., 1996. Dictionary of Environment and Sustainable Development. John Wiley \& Sons, Chichester.

Haggett, P., 1972. Geography: A Modern Synthesis. Harper and Row. New York.

Hribar,T., 1991. Uvod v etiko. Nova revija, Ljubljana.

Jones, G., 2004. People and Environment-A Global Approach. Prentice Hall, Harlow.

Kemp, D., 2004. Exploring Environmental Issues-An Integrated Approach. Routeledge, London and New York.

Kirn, A., 2004. Narava-družba-ekološka zavest. Fakulteta za družbene vede, Ljubljana.

Kryštufek, B. 1999. Osnove varstvene biologije. Tehniška založba Slovenije, Ljubljana.

Kupchella, C., Hyland, M., 1996. Environmental Science. Prentice Hall International, London.

Marsh, W., Grossa, J., 2002. Environmental Geography. Wiley, New York.

Mather, A., Chapman, K., 1995. Environmental Resources. Longman, Harlow.

Murdoch, J., 2006. Post-structuralist Geography. Sage Publications, London.

Odum, E.P., 1989. Ecology and Our Endangered Life - Support Systems. Linauer Associates, Sundarland.

Ošlaj, B., 2007. Etika narave. Zbornik Okoljske akademske mreže 2007/1, Fakulteta za družbene vede, Ljubljana, str. 7-21.

Plut, D., 2004. Zeleni planet? Prebivalstvo, energija in okolje v 21. stol. Didakta, Radovljica.

Požarnik, H., 1999. Proti toku. Družina, Ljubljana.

Radinja, D., 1974. Geografija in varstvo človekovega okolja. Geografski vestnik 45, Ljubljana, str. $110-120$.

Sustainable Development in a Dynamic World. 2003. The World Bank, Washington.

Špes, M., 1994. Degradacija okolja kot dejavnik diferenciacije urbane pokrajine (na izbranih slovenskih primerih) (doktorska disertacija). Oddelek za geografijo, Filozofska fakulteta, Ljubljana.

Špes, M., Cigale, D., Lampič, B., Natek, K., Plut, D., Smrekar, A., 2002. Študija ranljivosti okolja. Geographica Slovenica 35/1-2, Ljubljana.

Vintar Mally, K., 2006. Okoljevarstvena in socialnoekonomska protislovja držav v razvoju (doktorska disertacija). Oddelek za geografijo, Filozofska fakulteta, Ljubljana.

Vovk Korže, A., 1997. Spreminjanje pokrajine zaradi posegov človeka. Geografija v šoli VI/ 2 - 3, Ljubljana, str. 100 - 104.

Vrišer, I., 1998. Uvod v geografijo. Oddelek za geografijo, Filozofska fakulteta, Ljubljana. 


\section{EVALUATION OF GEOGRAPHICAL ENVIRONMENT AND ENVIRONMENTAL ETHICS}

\section{Summary}

In the $20^{\text {th }}$ century, the relationship between the human (i.e. society) and the geographical environment radically changed, since human interventions into the environment have become ever more intense. Parallel to the anthropogenic changes in the environment, a more complex knowledge about the functioning of the geosphere and about the negative impacts of the human, the consideration has also begun to change about the responsibility of the human race for the conservation of safe and healthy environment for the human race and other species, i.e. for future generations.

Accordingly, new values have to develop that will proceed from the fact that the human race is (only) part of the environment on which its existence depends. Global and local environmental problems and environmental movements lead, in a long run, towards the fundamental, common universal ecological/environmental values. This, however, does not mean that they are accepted by everybody, but at least by a great majority. The prevailing anthropocentric ethics is gradually giving way to global eco-centric ethics. Geographical investigations of the exhaustion of natural resources and of the degradation of geographical environment co-influenced the above-mentioned changes of values, and the environmental ethics in turn influences the changes in the evaluation of geographical environment.

The environmental ethics, or the environmental-protection ethics, is, as a rule, an ethical compass of the so-called shallow ecology and, with this, of the sustainable development model. In the first place, it is based on the protection of environment and natural resources (anthropocentric aspect), but it also includes some elements of the protection of nature (ecocentric aspect), particularly animal rights and conservation of the untouched nature to a limited extent.

The principles of environmental ethics present numerous contents-related challenges and methodological considerations to geography as the science about the human and geographical environment. Geographical environment underwent a radical anthropogenic transformation in the $20^{\text {th }}$ century, numerous regions of the world are polluted and landscapedegraded and natural resources are exhausted. In view of its theoretical-methodological and contents-related potentials and its role of a "bridge" between social sciences with humanities on the one hand and natural sciences on the other, geography is thus faced both with a chance and a task to add a concrete stone to the mosaic of the urgent change in the human attitude towards the environment, future generations and other species.

Therefore a multi-level - i.e. environmental (ecosystem), economic and social or ethic evaluation of the changed role of geographic environment is also one of the key factors in the search for lasting ways towards the welfare of humanity and the biosphere. Understanding of, knowledge about and evaluation of geographical environment as the source of raw materials and energy and the irreplaceable, healthy scene of human existence of the present generation will have to be expanded, so that geographical environment be treated as the scene of existence of all the species and of future generations. Geographical environment treated in 
such a way should become one of the fundaments for the effectuation of sustainable ethical starting-points (environmental ethics) and an integral part of general education. Geographical-environment-friendly attitude of the society as a whole can only be attained when people have become aware of the results of their own interventions into the environment.

The capacity of sensitive perception, apprehension and explanation of landscape changes, disharmony in the structure and dynamism of geographic environment, environmental dimensions of synergism of processes in the landscape and the identification of geographical potentials and limitations form the basis for a responsible attitude towards the environment and for adequate environmental steps both by the state and individuals. Geography calls attention to the urgency of multi-level apprehension of geographical environment, which, for the last three hundred years in particular, has been looked upon only as an inexhaustible reserve of goods, and the activities of economy have just copied the methods of mining.

Accordingly, in the turbulent nature of the society-vs.-environment relations, geography can play an important role in the imperative "ecologization " the world by emphasizing its complex material and spatial heterogeneity, as well as in the effectuation of environmentally (planetary interdependence and solidarity, »think globally-act locally«) and socially (social equity, intergeneration equality) relevant and related principles of environmental ethics. From the aspect of developmental-protective apprehension of geographical environment, the key geographical question is no longer "Where?", but "Why exactly there?". 